\title{
Strengthening the research agenda of educational integrity in Canada: a review of the research literature and call to action
}

\author{
Sarah Elaine Eaton ${ }^{*}$ (iD and Rachael Ileh Edino
}

\footnotetext{
* Correspondence: seaton@ucalgary.ca University of Calgary, Calgary, AB, Canada
}

\begin{abstract}
We present findings of a literature review on the topic of educational integrity in the Canadian context. Our search revealed 56 sources, published between 1992 and 2017. A historical overview showed a rise in the number of scholarly publications in recent years, but with an overall limited number of research contributions. We identified three major themes in the literature: (a) empirical research; (b) prevention and professional development; and (c) other (scholarly essay). Our analysis showed little evidence of sustained research programs in Canada over time or national funding to support integrity-related inquiry. We also found that graduate students who completed their theses on topics related to educational integrity often have not published further work in the field later in their careers. We provide five concrete recommendations to elevate and accelerate the research agenda on educational integrity in Canada on a national level. We conclude with a call to action for increased research to better understand the particular characteristics of educational integrity in Canada.
\end{abstract}

Keywords: Academic integrity, Academic misconduct, Academic dishonesty, Educational integrity, Canada, Literature review

\section{Introduction}

The purpose of this study was to investigate what research has been published in or about the Canadian context that contributes to the global body of knowledge about educational integrity and the related concepts of academic misconduct, academic dishonesty, and plagiarism. Academic misconduct continues to present a major problem in higher education (Altbach 2015; Colella-Sandercock and Alahmadi 2015; Leonard et al. 2015). In the 1980s, a counter-approach to punishing academic misconduct emerged, known as academic integrity (McCabe 1992; McCabe and Trevino 1993). Scholars specializing in the study of academic integrity promote the use of preventative and educational approaches over punitive responses to misconduct after it has happened (Bretag 2014; Busch and Bilgin 2014; Carroll and Duggan 2005). This includes developing a culture of integrity in which both students and educators are clear on the expectations and processes involved and the focus is on cultivating integrity as an educational process (Groark et al. 2001).

(c) The Author(s). 2018 Open Access This article is distributed under the terms of the Creative Commons Attribution 4.0 International License (http://creativecommons.org/licenses/by/4.0/), which permits unrestricted use, distribution, and reproduction in any medium, provided you give appropriate credit to the original author(s) and the source, provide a link to the Creative Commons license, and indicate if changes were made. 
We begin with an overview of previous literature reviews and then provide a justification for the current study, which focuses specifically on the Canadian higher education context. We conclude the introduction with the research question that guided the study.

The methodology section outlines our systematic approach to locating sources through an electronic search using five scholarly educational databases. We outline our inclusion and exclusion criteria for sources, highlighting the typologies of evidence we focused on. Our methodology and analysis were guided by Booth et al. (2012) systematic approaches to conducting literature reviews.

Our analysis begins with a brief historical overview, followed by a thematic analysis in which we present the strengths of Canadian research contributions to the field of educational integrity as well as some of the deficiencies. In our discussion, we contextualize our findings, providing concrete recommendations for further research in this area, as evidenced by our results. We conclude with a call to action to expand, strengthen and accelerate the Canadian research agenda on educational integrity, and for Canadian researchers to engage more fully in the global scholarly dialogue on integrity.

\section{Literature review and context}

Several previous reviews of the literature on educational integrity have informed the field (Bertram Gallant (ed.) 2012; Caravello 2007; Ercegovac and Richardson 2004; Fielden and Joyce 2008; Joyce 2007; Macfarlane et al. 2014; Wideman 2008). A quest to define and disentangle the concepts underpinning various terms relating to integrity are a common thread among previous literature reviews. Authors have been eager to understand the complexities of how plagiarism is defined (Caravello 2007; Macfarlane et al. 2014; Wideman 2008), including consulting various dictionaries and encyclopedias in search of a precise definition (Ercegovac and Richardson 2004). Others have turned to ancient conceptual or Latin etymological origins of integrity to seek clarity (Macfarlane et al. 2014). One common result is that it has been almost impossible for previous researchers to establish absolute definitions. Instead, these are concepts that demand that researchers, educators and policy makers employ not only their own critical thinking skills, but further, must acknowledge that complexities of educational integrity cross disciplinary boundaries and defy simplification.

Joyce (2007) pointed out that the term "educational integrity" was developed to broaden the scope of academic integrity, which has been used mainly to refer to tertiary education, while the former is intended to include all levels of education. The term educational integrity has been used to differentiate scholarly work conducted in the field from that of "the Center for Academic Integrity in the USA" (Joyce 2007, p. 190). The Center published an annotated bibliography covering 42 sources that the team of contributors deemed to be "top articles and book chapters", published between 1992 and 2012 (Bertram Gallant (ed.) 2012), and was included among those we consulted in our review of the literature.

We noted that since Joyce (2007) published his review the organization has been renamed to the International Center for Academic Integrity, with participants from various countries attending its annual conference and the organization now includes an active Canadian consortium, comprised of member organizations that are mostly higher education institutions. We emphasize however, that this affiliation should not be 
misunderstood as merely an extension of an American organization. Canada's philosophical, policy and educational approaches to academic integrity differ significantly from the United States in some respects. For example, the honour codes, modified honour codes and honour councils that have come to characterize the culture of many American higher education institutions (Broussard and Golson 2000; McCabe 1993, 2016; McCabe and Trevino, 1993, 2002, McCabe, Trevino, and Butterfield 1999; Wangaard 2016) are largely absent from Canadian campuses. Another characteristic of the Canadian context is that the term academic integrity is used more widely and often. As such, we use both terms throughout our paper interchangeably, deliberately choosing not to privilege either term.

Previous reviews of the literature that have highlighted contributions to research from particular global regions include Joyce's (2007) and Fielden and Joyce's (2008) reviews, both of which offer an analysis of research from Australasian authors. Others have addressed the topic of academic integrity more broadly. Wideman's (2008) review of the literature addressed questions such as who cheats, why students cheat and cheating culture, among others, but interestingly, although Wideman was working in a Canadian context, she opted not to take the unique angle of Canada's contributions to the literature in her review. As a result, we found no published reviews of the literature that mentioned Canada's contributions to the field in an intentional manner.

To a large extent, Canada has gone quietly unnoticed in some respects. This may be due the fact that the country has not had widespread issues that have emerged in the national news on the same scale as they have in other countries, such the United Kingdom and Australia, where contract cheating, in particular, has emerged as a national news story on several occasions (Australian Government, Tertiary Education Quality and Standards Agency, 2015; QAA 2016, 2017). In the UK, contract cheating has been called a "cheating crisis" by the press (Mostrous and Kenber 2016). In contrast, Canada, has experienced no such crises in the media, at least, not yet.

There have been instances where issues relating to academic misconduct have appeared in the national news, such as reports about the University of Regina regarding significant student cheating, hacking into a Dean's computer account to change grades and allegations of teaching assistants taking bribes from students (Leo 2017a, b, 2018). Another high-profile case relating to plagiarism caught the attention of the public when the former director of the Toronto District School Board, Chris Spence, was dismissed from his role as director of the board when it was found he had plagiarized his doctoral thesis (Alphonso 2017). While these stories have brought the topics of plagiarism and cheating into the public's view, they were single events of a small scale. Canada has remained inconspicuous in terms of large-scale media attention with regards to issues relating to cheating and violations, potentially leading to the conclusion that Canada may be less affected than other nations. We contend that such an assumption would be erroneous, as there are indications that Canada is not immune to issues relating to violations of integrity. In addition to the small-scale events that have made the news recently, Clarke and Lancaster (2006) argued that Canada was among the top four nations where students engage in contract cheating behaviours. As we will show in our study, few large-scale studies have been conducted in Canada, with the exception of one conducted by Christensen Hughes and McCabe (2006a, b) over a decade ago. This review of the research was driven, in part, to discover what research has been 
undertaken that could set the stage for a larger national research agenda relating to educational integrity in this country.

\section{Rationale for the current study}

We situate this work within the field of educational integrity research, which, as Macfarlane et al. (2014) argued, "does not represent a mature sub-field of enquiry in the same way as assessment and feedback, for example" (p. 341), and also within the context of Canadian research, which faces its own struggles in terms of elevating its scholarly prominence on the global stage. The issue of research in Canada reached a new of urgency level when a nine-member Advisory Panel on Federal Support for Fundamental Science was struck in June 2016 to examine the state of research and funding at a national level (Naylor et al. 2017). Dubbed "the Naylor report" by the media and scholars, the panel's report became a topic of national interest when it was released in 2017 (Shen 2017). The panel defined research as "an umbrella term covering both 'science' and 'scholarly inquiry"' (p. i). A key finding of the panel was that Canada's research competitiveness was lagging behind that of its international peers.

Reflecting on the findings of the Naylor report, we wondered if and how Canada might lag behind its international peers in contributions to the field of educational integrity and if so, how might that be ameliorated? A literature review is the first step in identifying a research problem (Creswell 2012), or in our case, establishing a foundation for a larger, and possibly national, research agenda, on educational integrity. As a result, we generated this research question, which guided our study: What major themes emerge from scholarly and research literature about academic integrity in the Canadian context?

\section{Methodology}

In this section we outline the methodology for our review, including some of the complexities encountered during our study and methodological decisions we had to make in terms of inclusion and exclusion criteria. Although our literature review showed that no previous reviews had been conducted that explicitly considered Canadian contributions to the field, we nevertheless conducted a search of Google scholar and institutional databases to ensure that similar studies had not been conducted previously. Upon confirming this, we undertook the present study and registered our project at the Open Science Framework on February 18, 2018 (DOI: https://doi.org/10.17605/OSF.IO/98WFM).

\section{Search method}

We conducted a methodical search of sources, drawing on five major databases available through our institutional library: (a) Academic Search Complete, (b) Education Research Complete, (c) ERIC, (d) ProQuest Dissertations and Theses, and (e) Google Scholar. We concentrated on databases related to social sciences and education to align with our research expertise.

\section{Inclusion and exclusion criteria}

One indicator of search quality is a list of search terms (Booth et al. 2012) which we have included in Table 1. An additional indicator of quality is the search syntax used to combine the terms (Booth et al. 2012). We employed a combined strategy using the syntax 
Table 1 Search Term Categories

\begin{tabular}{ll}
\hline Search Term Category 1 & Search Term Category 2 \\
\hline Educational integrity & Canada \\
Academic integrity & \\
Academic misconduct & Canadian \\
Academic dishonesty & \\
Plagiarism & \\
\hline
\end{tabular}

indicator "and" to include terms from both categories (see Table 1). A source had include to at least one term from Category 1 and at least one term from Category 2 to be included. We specifically searched for combinations of our search terms in the title (TI), Abstract $(\mathrm{AB})$ and keywords (KW) of sources in each of our selected databases, using quotation marks around search terms to ensure they were searched in their entirety.

\section{Exclusion criteria}

The exclusion criteria for our study fell into two broad categories: (1) non-scholarly sources and (2) scholarly sources that did not facilitate our primary objective of better understanding the research that has been conducted in the Canadian context.

Our search focused on literature of a research, scholarly, and authoritative nature, necessitating the exclusion of non-scholarly sources including, but not limited to, (a) institutional reports and policy documents; (b) newspaper articles and other popular media sources; (c) "grey" literature such as blogs, editorials, and letters to the editor; and (d) social media outputs such as posts on Facebook and Twitter. Because our study was focused on the Canadian context, further exclusion criteria included (e) studies not primarily focused on Canada and (f) comparative studies or multi-institutional studies involving a Canadian institution.

\section{Inclusion criteria and typology of evidence}

We subscribe to Petticrew and Roberts' (2006) notion that typologies of evidence can provide a useful framework for answering the research questions guiding a literature review. We initiated our search with the following typologies of evidence in mind: (a) experimental, (b) quantitative, (c) qualitative, and (d) mixed methods studies, (e) policy research, (f) literature reviews, and (g) other scholarly sources within our search parameters (e.g., scholarly essays). These were not inclusion criteria, but rather an overarching guide to focus our search.

Under the umbrella of these typologies we conducted a rigorous search for high-quality available sources including (a) peer-reviewed journal articles, (b) conference papers (peer-reviewed and non-peer-reviewed), (c) books and book chapters, and (d) theses and dissertations. With the aim of casting a wide net to find as many sources as possible that met our search criteria, we searched for works published from 1900 to 2017, inclusive. According to our results, the earliest published work in Canada that met our criteria was released in 1992, so although our initial search was chronologically broader in its scope, the results were delimited to works published in 1992 and thereafter.

Initially, we sought to find research written by Canadians about the Canadian context. However, our decision-making process was complicated when we found studies 
that appeared to have been conducted about Canada but were written by scholars who identified as being located in other countries. Ultimately, we chose to include these works in our review along with those written by authors who were identified as being situated in Canada at the time the source was published.

\section{Reference management software}

We used Endnote version 8.2 (for Mac) as our reference management software. We used the automated citation download function available through our institutional library service to download citations and abstracts whenever possible. In cases where this was not possible, we entered the bibliographic information manually into Endnote.

In most cases, .pdf copies of sources were available to us through our institutional library databases. In cases of more obscure sources, we requested them through our institutional document delivery service (formerly known as inter-library loan), receiving six sources through service (Butakov, Shcherbinin, Diagilev and Tskhay 2013; Das and Henderson 2015; Hexham 1992; Kier 2015; Strawczynski 2004; Taylor et al. 2004), resulting in a complete collection of the 56 sources in our final selection.

\section{Findings and analysis}

We conducted a total of 130 discrete and systematic searches, using a combination of our search terms and limiters of title (TI); abstract (AB) and key words (KW), across our five selected databases, resulting in 511 possible sources, each of which was screened to ensure that it met our inclusion criteria. Of these, 56 sources remained and were included in our study.

Figure 1 shows the search results, and more detailed explanation can be found on our entry in the Open Science Framework, which details the results for each of the 130 individual searches, showing search term combinations for each limiter (TI, KW and AB) and database.

Researcher 1 conducted the analysis portion of the study, using Booth et al.'s (2012) systematic approach to literature analysis, beginning first with immersing oneself in the

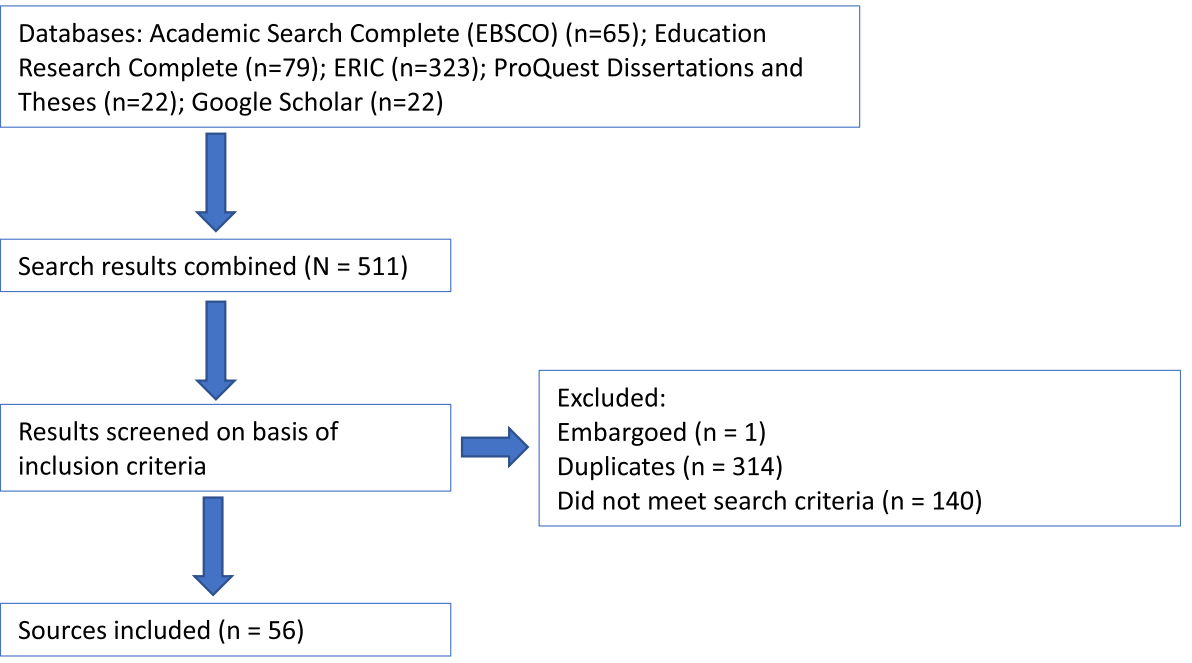

Fig. 1 Systematic Search Term Results 
sources, and then assessing the evidence base. The assessment included reviewing each source in detail, and then endeavouring identify differences among them, as well as commonalities between them. Sources were analyzed from both a technical perspective and a qualitative synthesis perspective (Booth et al. 2012), beginning with a historical overview, followed by an analysis of the hierarchy of typologies, and concluding with a critical reflection of key themes.

\section{Historical overview}

Our search resulted in 56 sources with publication dates ranging from 1992 to 2017. This was noteworthy because although contributions to scholarly journals on the topic of plagiarism can be traced back to the nineteenth century in Europe (Gallwey 1879), we found little evidence of contributions to the scholarly dialogue on the topics of plagiarism, academic misconduct, or academic integrity from Canadian scholars until almost a hundred years later.

The sources we located spanned 25 years of publication, with gaps in 1993, 1994, 1997, 1999 and 2000, with notable increases in 2012, 2014 and 2016 (see Fig. 2).

Because this study was limited to the Canadian context, we cannot draw conclusions about if or how the increase in recent years may represent developments in the field on a global scale. Within the parameters of the current study, the increase would seem to indicate that the issue of academic integrity is gaining some momentum as a research topic in Canada, though it remains limited.

\section{Typologies of evidence}

An assessment of the evidence base can include an analysis of the typologies of evidence collected, as an indicator of overall quality of the corpus of work selected. The

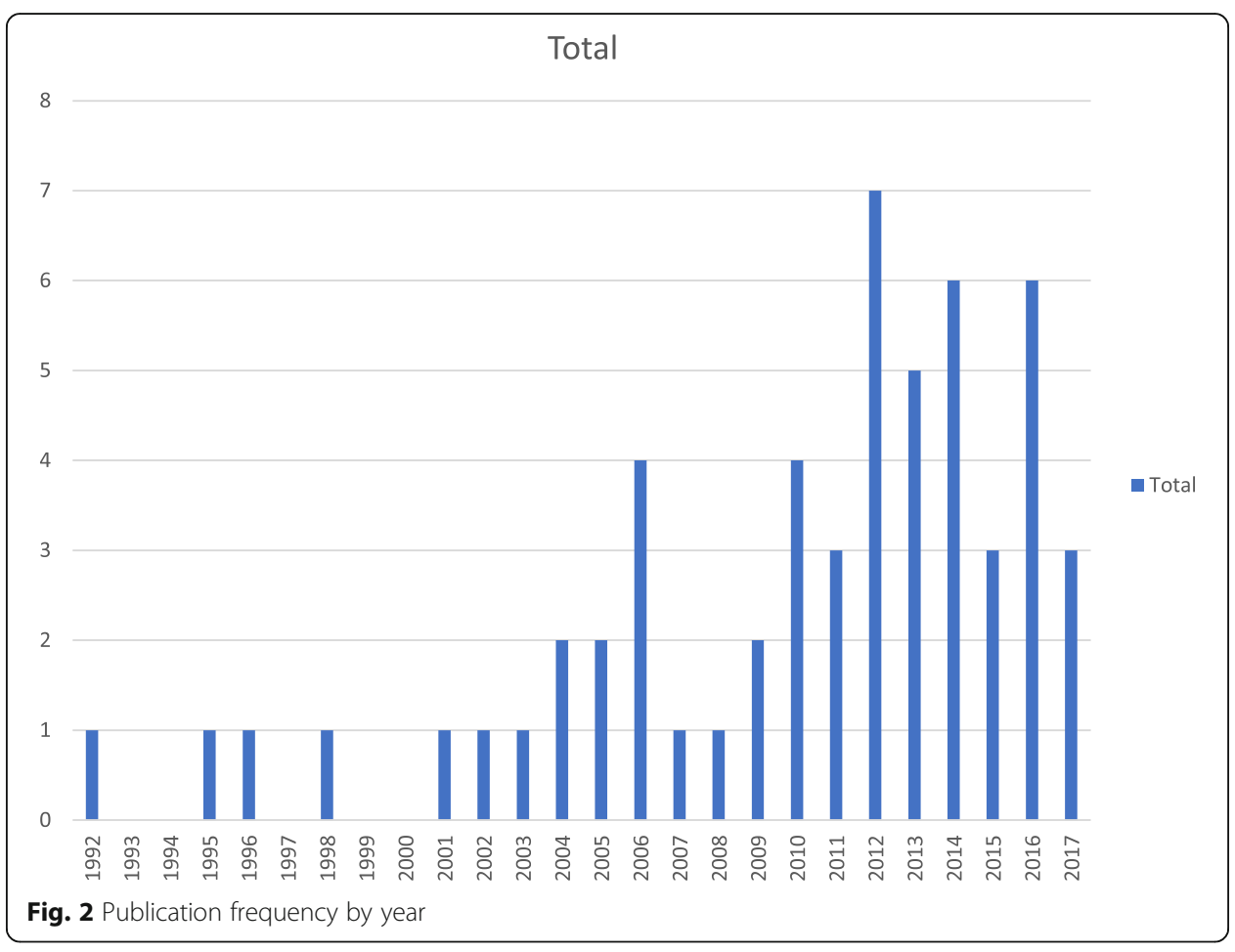


assessment of evidence using a classification of typologies of evidence can be problematic because there is no analysis of the rigour of the works studied (Booth et al. 2012). Furthermore, Booth et al. (2012) acknowledge that "the randomised controlled trial (RCT) is considered the gold standard study design" (p. 105, emphasis in original), but such studies are more prominent in the health and sciences fields than in the humanities and social sciences, where we focused our review. We offer this analysis of typologies not as a means to further propagate hegemonic research design hierarchies, but rather to establish a broad understanding of Canada's contributions to the field. We have analysed our corpus of sources, using Booth et al. (2012) classifications of descriptive / qualitative or analytical / quantitative, as a point of reference. We included literature reviews, policy analyses and archival analyses under the heading of descriptive/ qualitative studies. We further interpreted Booth et al. (2012) categorization of analytical research to include mixed methods designs. Table 2 shows that descriptive studies have been somewhat more prominent (55.4\%) than analytical studies (44.6\%).

\section{Types of knowledge mobilization}

Given that the type of publication, such as "books, journal articles, reports and other media" (Booth et al. 2012, p. 214) can be an additional indicator of source quality, we analysed the knowledge mobilization type, as an additional assessment criterion. We have further refined the list proposed by Booth et al. (2012) into: peer-reviewed journal articles; book chapters; conference presentations; reports (including non-peer reviewed articles); theses and dissertations; and grey literature (including web pages). As we found no monographs or edited books during our search, these have not been included. Table 3 offers an overview of our findings.

Peer-reviewed journal articles have dominated the ways in which studies about educational integrity in or about the Canadian context have been mobilized with almost $54 \%$ of sources falling into this category. It was of some concern (and surprise) to us, that over $21 \%$ of our total sources were comprised of graduate theses. While student

Table 2 Analysis of Typologies of evidence

\begin{tabular}{|c|c|c|}
\hline Typology & $\begin{array}{l}\text { Number of } \\
\text { studies (\%) }\end{array}$ & Sources listed by author and date \\
\hline $\begin{array}{l}\text { Descriptive / } \\
\text { Qualitative }\end{array}$ & $31(55.4)$ & $\begin{array}{l}\text { Bens (2010); Butakov (2014); Butakov and Barber (2012); Christensen Hughes } \\
\text { and McCabe (2006b); Colella-Sandercock (2016); Colella-Sandercock and } \\
\text { Alahmadi (2015, 2016); Eaton 2017; Eaton et al. 2017; Edmonds 2006; Evans- } \\
\text { Tokaryk (2014); Fredeen (2013); Griffith (2013); Hexham (1992, 2013); Hu } \\
\text { (2001); Kara and MacAlister (2010); Kelleher (2016); Lytton (1996); MacLeod } \\
\text { (2014); Neufeld and Dianda (2007); Oliphant (2002); Paterson et al. (2003); } \\
\text { Strawczynski (2004); Taylor et al. (2004); Usick (2005); Wideman (2008, 2009, } \\
\text { 2010, 2011); Zivcakova, Wood, Baetz and De Pasquale et al. (2012a) }\end{array}$ \\
\hline $\begin{array}{l}\text { Analytical / } \\
\text { Quantitative }\end{array}$ & $25(44.6 \%)$ & $\begin{array}{l}\text { Austin, Simpson, and Reynen (2005); Austin, Collins, Remillard, Kelcher, and } \\
\text { Chuia (2006); Baetz et al. (2011); Bokosmaty et al. (2017); Butakov, Dyagilev, \& } \\
\text { Tskhay, 2012 (2012); Butakov and Shcherbinin (2009); Butakov, Murzintsev, } \\
\text { Tskhai (2016); Butakov, Shcherbinin, Diagilev, \& Tskhay (2013); Christensen } \\
\text { Hughes and McCabe (2006a); Colella (2012); Colella-Sandercock and } \\
\text { Alahmadi (2015, 2016); Das and Henderson 2015; Eaton (2017); Edmonds } \\
\text { 2006; Evans-Tokaryk (2014); Genereux and McLeod 1995; Griffith 2013; Hage } \\
\text { 2010; Jurdi et al. (2011, 2012); Kier (2013, 2014a, 2015); Miron (2016); Thyret- } \\
\text { Kidd (2012); Woods 1998; Woods and Negrin 2016; Zivcakova, Wood, } \\
\text { Forsyth, Dhillon, Ball, Corolis, Petkovski (2012b); Zivcakova et al. (2014); }\end{array}$ \\
\hline Total & $56(100)$ & \\
\hline
\end{tabular}


Table 3 Distribution of research outputs by knowledge mobilization type

\begin{tabular}{|c|c|c|}
\hline $\begin{array}{l}\text { Knowledge } \\
\text { mobilization type }\end{array}$ & $\begin{array}{l}\text { Number } \\
(\%)\end{array}$ & Sources listed by author and date \\
\hline $\begin{array}{l}\text { Peer-reviewed journal } \\
\text { articles }\end{array}$ & $30(53.6 \%)$ & $\begin{array}{l}\text { Austin et al. (2006); Austin et al. (2005); Baetz et al. (2011); Bokosmaty et al. } \\
\text { (2017); Butakov and Barber (2012); Butakov et al. (2012); Christensen Hughes } \\
\text { and McCabe (2006a, 2006b); Das and Henderson 2015; Genereux and } \\
\text { McLeod 1995; Jurdi et al. (2011, 2012); Kara and MacAlister (2010); Kier } \\
\text { (2014a, 2014b); Lytton 1996; Paterson et al. 2003; Strawczynski (2004); } \\
\text { Taylor et al. (2004); Wideman (2008, 2011); Zivcakova et al. (2014) }\end{array}$ \\
\hline $\begin{array}{l}\text { Theses and } \\
\text { dissertations }\end{array}$ & $12(21.4 \%)$ & $\begin{array}{l}\text { Colella (2012); Hage (2010); Miron (2016); Thyret-Kidd (2012); Woods (1998); } \\
\text { Bens (2010); Fredeen (2013); Hu (2001); Kelleher (2016); MacLeod (2014); } \\
\text { Usick (2005); Wideman (2009). }\end{array}$ \\
\hline $\begin{array}{l}\text { Conference } \\
\text { presentations }\end{array}$ & $9(16.1 \%)$ & $\begin{array}{l}\text { Butakov (2014); Butakov et al. (2016); Colella Sandercock and Alahmadi (2016); } \\
\text { Eaton et al. (2017); Kier (2013, 2014b; 2015); Wideman (2010); Woods and } \\
\text { Negrin (2016) }\end{array}$ \\
\hline $\begin{array}{l}\text { Non-refereed articles } \\
\text { and reports }\end{array}$ & $3(5.3 \%)$ & Hexham (1992); Neufeld and Dianda (2007); Oliphant (2002) \\
\hline Book chapters & $1(1.8 \%)$ & Butakov et al. (2013) \\
\hline Grey literature & $1(1.8 \%)$ & Hexham 2013 \\
\hline Total & $56(100 \%)$ & \\
\hline
\end{tabular}

research most certainly makes an important contribution to the field, we noted that only Colella-Sandercock (née: Colella), Wideman and Hage published or co-published after their dissertations, at least as far as our results showed. There is the possibility that some of those who have successfully produced graduate theses have yet to publish the results of their work (e.g. in peer reviewed journals), but nevertheless, there remains a troubling question about why novice researchers who complete their graduate research projects on topics related to educational integrity did not seem to go on to produce further research outputs after they graduate.

The teams of Christensen Hughes and McCabe (2006a, b); Jurdi et al. (2011, 2012); and Taylor, Paterson and Usick (Paterson et al. 2003; Taylor et al. 2004), each co-authored two articles. We noted an interesting phenomenon during our review process about these teams. The Canadian Journal of Higher Education, which is among the most reputable journals on educational research in the country, conferred their annual Sheffield Award upon Christensen Hughes and McCabe 2006a article, and later on Jurdi et al. (2011) for their contribution. The journal confers one award each year for the best journal article, as determined by the editors, published in the previous year (Canadian Society for the Study of Higher Education 2018) and we found it of interest that the award was conferred for articles relating to academic integrity twice in the same decade, each time with authors working as a collaborative research team. We further noted that Taylor et al. (2004) acknowledged research funding for their work from the Social Science and Humanities Research Council (SSHRC), Canada's most highly esteemed national research funding body in the social sciences and humanities. While these observations present inconclusive evidence about whether those who work in teams are more likely to be recognized for their research, either in terms of funding or awards, it is noteworthy that those who have been mostly highly recognized by their scholarly peers in this field in Canada have worked in collaboration with others. Our final observation about these collaborations, offered with a note of regret, is that none of the highly recognized research teams appeared to have further developed sustained 
programs of research in the area of educational integrity, as we found no further evidence of publication after initial recognition of their contributions.

One final note about knowledge mobilization, is that we observed that the most prolific among the authors whose work we analyzed was Butakov, who authored or co-authored six research outputs, including one conference proceeding (Butakov 2014), one book chapter (Butakov, Shcherbinin, Diagilev and Tskhay 2013) and four peer-reviewed articles (Butakov and Barber 2012; Butakov, Dyagilev and Tskha 2012, Butakov, Murzintsev and Tskhai 2016; Butakov and Shcherbinin 2009), including both analytic and descriptive contributions. In our analysis, we found the work conducted by Butakov and his colleagues to be among the most technical, with a focus on computer science and software development.

\section{Thematic analysis}

Typologies of evidence are useful for developing a broad understanding of overall contributions. Typological analyses are further complemented by a thematic scrutiny of the content. Our thematic analysis was guided by the methodological question posed by Booth et al. (2012): "What themes or constructs are present between or within individual studies?" (p. 103). Our findings showed three key themes evident in the literature (a) empirical research (including one literature review); (b) professional development and prevention; and (c) other.

\section{Theme 1: Empirical research}

In terms of themes or constructs found between studies, we identified five sub-categories of empirical research: (a) focus on students; (b) focus on faculty; (c) combined student and faculty focus (d) research on policy or institutional approaches; and (e) literature review of empirical research. In the sections that follow, we discuss each in further detail.

Sub-theme 1a: Research focusing on students From one of the earlier sources we encountered (Genereux and McLeod 1995) to one of the more recent (Bokosmaty et al. 2017), students' perspectives constituted a large proportion of the empirical research. Christensen Hughes and McCabe's (2006b) seminal study offered an in-depth scholarly review of academic integrity in Canada, with a student focus at its core.

We found quantitative research designs to be the most prevalent in student-focused research (Austin, Simpson and Reynen 2005, Austin, Collins, Remillard, Kelcher and Chuia 2006; Bokosmaty et al. 2017; Christensen Hughes and McCabe 2006a; Colella 2012; Das and Henderson 2015; Evans-Tokaryk 2014; Hage 2010; Jurdi et al. 2011, 2012; Miron 2016). Qualitative interviews were used as the primary data collection method less often (Fredeen 2013; Wideman 2009, 2010, 2011), while focus groups were used in only two studies (Bens 2010; Evans-Tokaryk 2014). Other approaches involved using presentations in class, class discussions, and quizzes to gather data (Baetz et al. 2011; Kier 2013, 2014a, 2014b; Zivcakova, Wood, Baetz, and De Pasquale, 2012, Zivcakova, Wood, Forsyth, Zivcak, Shapiro, Coulas, et al., 2014). This range of research designs demonstrates diversity among these studies, which concentrate on how students perceive, understand, and self-report academic misconduct and plagiarism. 
A number of studies focused on a specific academic disciplines including health sciences and nursing (Austin, Simpson and Reynen 2005, Austin, Collins, Remillard, Kelcher and Chuia 2006; Miron 2016; Paterson et al. 2003; Wideman 2009, 2010, 2011); business (Baetz et al. 2011. Taylor et al. 2004); and engineering (Hu 2001). Otherwise, there appeared to be little research conducted about particular areas of study, which creates gaps for institutional administrators. If institutions aim to develop evidence-informed policies and procedures, they may be left to consider literature from other jurisdictions which may not necessarily reflect the Canadian context.

Although there has been extensive literature written about the situation of international students for whom English is an Additional Language (Altbach 2015; Bretag 2017), we found only two instances of student-focused research that addressed this particular group of learners (Fredeen 2013; Hu 2001), both of which were graduate student theses. Given that in 2017, over 220,000 international students were enrolled in Canadian post-secondary institutions, constituting just over $11 \%$ of the total student population (Statistics Canada 2017b), we contend that this additional gap in student-centered research on academic research in the Canadian context is problematic.

Sub-theme 1b: Research focusing on faculty members MacLeod's (2014) doctoral dissertation, which had a mixed methods research design including a policy analysis and a faculty survey was the only empirical study we found to focus exclusively on faculty. MacLeod studied the attitudes and behaviours of over 400 faculty members across Canada. He found that, according to faculty, the most significant factors contributing to academic misconduct included students not understanding what is expected of them; institutional policies that are too lenient; external pressures on students (e.g. workload, jobs, pressure to succeed) and cultural factors. Given this singular result, it would appear that the role and experiences of faculty within the Canadian context merits deeper inquiry.

Sub-theme 1c: Research with a combined focus on faculty and students A number of studies examined faculty and student perspectives together (Evans-Tokaryk 2014; Paterson et al. 2003; Taylor et al. 2004; Usick 2005; Zivcakova, Wood, Baetz, and De Pasquale, 2012). Evans-Tokaryk (2014) studied remix culture as it relates to plagiarism, with data being collected through a faculty survey and student focus groups. Among the findings were that both groups were unclear about the expectations around the use and re-use of text, corroborating MacLeod's (2014) findings that unclear expectations may lead to increases in academic misconduct, as well as escalate both faculty and student anxiety about what is acceptable.

Zivcakova, Wood, Baetz and De Pasquale (2012a) conducted a qualitative analysis of faculty members' perceptions of academic integrity in the classroom after they observed students participate in an interactive presentation on academic integrity. This study appeared to mirror Zivcakova et al.'s (2014) later examination of students' responses to what appeared to us to be the same academic integrity presentation.

Taylor et al.'s (2004) institutional ethnography of a business school in central Canada highlighted the tensions between policy and practice, particularly when faculty members do not follow institutional policies, resulting in inconsistent experiences for students. Unlike MacLeod's (2014) study, which found that perceptions among faculty 
members that institutional leniency contributed to academic misconduct, Taylor et al. (2004) found that the institution's "hard stand" (p. 164) was problematic for faculty members who viewed plagiarism as a continuum. Although an ethnography of a single institution cannot be compared to the findings of a national study, the discrepancy would seem to indicate that further research is needed to better understand faculty attitudes towards policies in Canadian higher education institutions.

Sub-theme 1d: Research focusing on policy, law or institutional approaches We found eight sources in this sub-category (Eaton 2017; Griffith 2013; Kara and MacAlister 2010; Kelleher 2016; Lytton 1996; MacLeod 2014; Neufeld and Dianda 2007; Woods 1998), of which two concentrated specifically on the province of Ontario (Griffith 2013; Neufeld and Dianda 2007).

The earliest of these studies (Lytton 1996) examined the "only four officially substantiated cases of serious academic misconduct.... (that) have come into the public domain in Canada" (p. 224). Lytton's article examined cases of what we might call "research misconduct" or "publication ethics" today concentrated faculty misconduct, rather than students. Of particular interest in this article, is the historical overview of the development of academic and research integrity policies in Canada, noting that the mid-1990s was a pivotal time for research ethics as it was the first time that institutions were required to develop polices on such matters in order to remain eligible for federal research funding.

Neufeld and Dianda's (2007) survey of policies and procedures regarding academic misconduct at Ontario universities showed inconsistencies among institutional policy definitions relating to academic misconduct. A decade later, a comparative analysis of 20 Canadian post-secondary institutions showed that such inconsistencies remain an issue of concern (Eaton 2017). Similarly, MacLeod's (2014) doctoral dissertation examined 17 institutions using a documentation analysis combined with a faculty survey relating specifically to institutional policy and practice. MacLeod also found that inconsistency was an issue, with institutional polices not being enforced consistently, leaving faculty members with "a sense of futility when it comes to dealing with academic dishonesty" (p. 95).

In 2013, Griffith used a semiotic approach to analyze the websites of 22 universities in the province of Ontario, concluding that academic integrity websites are an institution's "most accessible and most dynamic form of ... education" (p. 17). Overall, policy research about academic integrity in Canadian secondary or higher education has been relatively scant.

This section concludes with commentary about the three studies we found that examined academic integrity from a legal perspective (Kara and MacAlister 2010; Kelleher 2016; Woods 1998). We turn first to the work of Kara and MacAlister (2010), who proposed a restorative justice approach to discipline, as an alternative to punitive processes that characterize academic appeal and student discipline boards. Their conceptual work analyzed how student discipline boards operate in general, critiquing their processes from a restorative justice perspective. They concluded with a call to reconceptualize "the traditional model that has been adversarial in nature" (p. 452) in favour of building learning communities that are more caring and collaborative. 
Two doctoral studies compared academic integrity policies and Canadian law. Woods (1998) examined discrepancies between academic integrity and "natural justice" (p. iii), while Kelleher's (2016) dissertation included a qualitative archival study of 140 Canadian court decisions relating to academic misconduct to "create a legal base of Canadian common law principles to inform various aspects of student academic discipline in Canadian public universities" (p. 4). Woods (1998) identified a need for academic integrity policies and codes of conduct to be clear and specific, while Kelleher's findings indicated a need for higher educational institutions to develop policies in compliance with existing laws and provide further training to faculty. Although almost 20 years separated es was highlighted. In other words, paying attention to established procedures to ensure the rights of the individual are respected remains an important issue in the Canadian academic context.

Sub-theme 1e: Literature review Wideman's (2008) literature review on academic dishonesty appears to be a precursor to her 2009 doctoral dissertation on nursing students. The literature review was broad in scope and did not address academic integrity in the Canadian context directly, though she dedicated a paragraph to "Western culture" (p. 5). It was the sole literature review among our findings.

\section{Theme 2: Professional development and prevention}

Sub-theme 2a: Professional development These articles concentrated on classroom strategies for educators to support academic integrity and decrease misconduct (Eaton et al. 2017; Colella-Sandercock 2016; Colella-Sandercock and Alahmadi 2015, 2016; Kier 2015; Oliphant 2002; Paterson et al. 2003, Strawczynski 2004).

Oliphant's (2002) professional development article focused on what she called "cyber-plagiarism", and showed itself to avant-garde for its time, as it was the first source we found to address the issue of what we now call contract cheating (Lancaster \& Clarke, 2006) and also the first among our results to discuss the use of text-matching software (i.e. Turnitin ${ }^{\mathrm{TM}}$ ).

Sub-theme 2b: Prevention Related to professional development, a similar body of work addressed the issue of prevention, and was dominated by the work of one researcher (Butakov) in collaboration with others interested in the development of software to detect plagiarism (Butakov and Barber 2012; Butakov, Murzintsev and Tskhai, 2016; Butakov and Shcherbinin 2009; Butakov, Shcherbinin, Diagilev and Tskhay 2013). Interestingly, these studies seemed to stand apart from all the others in that their focus was highly technical and focused intently on computer science.

Others working in this space have included Strawczynski (2004), who addressed the use of Turnitin ${ }^{\mathrm{Tm}}$ in Canadian academic institutions, presenting arguments for and against the adoption of text-matching software at both secondary and tertiary levels.

The most recent contributions from researchers working in this area included Kier (2015) and Woods and Negrin (2016). Kier (2015), examined the use of technology-based games to raise awareness about plagiarism, while Woods and Negrin (2016) used a massive open online course to teach first-year international nursing 
students about academic integrity and then measured their self-perceptions of improvement using a questionnaire.

Overall, there has been less treatment of the topics relating to prevention or educational development for faculty, particularly when compared the amount of research that has been done about students, or faculty perceptions and attitudes.

\section{Theme 3: Other: Scholarly essay}

Our thematic analysis concludes with the earliest substantive Canadian contribution to the dialogue on plagiarism that we encountered. We included Hexham's web resources for their historical significance. Hexham's (1992) essay was originally posted on his personal webpage hosted by the University of Calgary, with revisions in 1999 and 2005. A version was also published in an online serial, Humanist: Humanities Computing (1992), making it the earliest scholarly publication about academic integrity in Canada that we found.

The essay was later re-released in PDF format in 2013 and posted on ResearchGate. A comparison of the ResearchGate and other online versions showed they were identical, which we determined to be a re-release of a previous work in a new format rather than a case of self-plagiarism. Hexham uses the same title and includes the same publication and revision dates on his website and in the ResearchGate version. His work is informal but rigorous, scholarly, and authoritative, as evidenced by Google Scholar citations of the work, numbering above 30 at the time of this study.

In conclusion, although we found a breadth of topics addressed across the various sources, we found that overall, the field lacks depth in terms of the number of studies on the same topics. Further, we identified an imbalance in our thematic analysis, in terms of the amount of empirical research, versus those on prevention and professional development. We found fewer research contributions on how to prevent violations of integrity or help faculty develop the skills necessary to address breaches effectively. The amount of research that we found, across the past 25 years, shows that Canada's treatment of educational integrity as a research topic has been arguably impoverished, in both quantity and consistency. As we will elaborate on further in our discussion, we view this not as a deficiency, but rather as an opportunity and a call to action.

\section{Discussion}

The existing research has focused largely on student perspectives. Our findings aligned with those of Fielden and Joyce (2008) who also found that papers focusing on students dominated the literature. Our search uncovered only one source focusing explicitly on faculty perspectives (MacLeod 2014) and even though other papers considered faculty perspectives, overall the educator voice was underrepresented in the Canadian literature, demonstrating an imbalance in the ways in which scholars have directed their research.

Of the policy research we found, two focused on regional contexts related to one specific province, Ontario (Griffith 2013; Neufeld and Dianda 2007). Two additional sources examined institutional policy on a national level (Eaton 2017; MacLeod 2014), neither of which examined more than 20 institutions in a country with dozens if not hundreds, depending how they are counted. This seems to indicate that large-scale research in the Canadian context is, as yet, an underdeveloped area of inquiry. This 
becomes more evident when considering the global context, in which large-scale national (Bretag et al. 2018; Harper et al. 2018; McCabe 2016; McCabe et al. 2001); and multi-national (Foltýnek and Glendinning 2015; Glendinning 2013, 2014) research has been underway in Australia, the United States and Europe for some time.

Similarly, large government agencies such as the Tertiary Education Quality and Standards Agency in Australia (Bretag 2017) and the Quality Assurance Agency for Higher Education (QAA) in the UK (QAA 2016, 2017) have made strides in mobilizing knowledge around academic integrity for educators, policy makers and the public, drawing on the expertise of researchers from those countries. In Canada, the Council of Ministers of Education, Canada (CMEC) (2018) has yet to initiate any similar large-scale advocacy work around educational integrity that we are aware of. When we ran a search of CMEC's publications, replicating the same Category 1 search terms we employed in our literature review (educational integrity, academic integrity, academic misconduct, academic dishonesty and plagiarism). The search returned no results, which could be interpreted as an indication that the issue of educational integrity broadly has not yet garnered the attention of the national ministerial council charged with overseeing higher education in Canada. Given that other countries are addressing these questions with large-scale research and policy work, as well as government input, while contributions from Canadians seem limited to local and provincial contexts, with few examinations of what is occurring at a national level, it would suggest that Canada is lagging behind in its scholarship, policy and contributions to the global dialogue on integrity.

Canada's Advisory Panel on Federal Support for Fundamental Science argued that research was fundamental "to inform evidence-based policy making" (Naylor et al. 2017, p. xii). However, when it comes to policies of higher education institutions as individual organizations, and Canada as a country, there seems to be little evidence in the literature that policy relating to academic integrity is evidence-based. This may be due to a lack of evidence or research from the Canadian context relating to educational integrity broadly.

\section{Limitations}

As Booth et al. (2012) point out, a literature review can be comprehensive without necessarily being exhaustive. As such, we recognize that despite our best efforts, the results may not be exhaustive. Authors making contributions to the topic in the Canadian context may not have used the specific search terms we selected for our study. We recognize this as a limitation to our study.

Another important limitation we note is that our work was limited to sources published in English, given our language proficiency in French was inadequate to review scholarly work in Canada's other official language. Similarly, we were further limited in terms of discovering work written in any of Canada's Indigenous languages on this topic. This presents a consideration for future research in this area.

Finally, we acknowledge that although two researchers contributed to this study, the second was a student research assistant provided for a limited number of hours. As such, the analysis portion of the study was conducted by the first author. Although other literature reviews have been published with a single author conducting the analysis (Joyce 2007; Wideman 2008), we recognize that literature reviews today are considered more reliable when analysis is undertaken by two or more parties (Booth et al. 2012). We concede the single-researcher analysis as a limitation of the work. 


\section{Directions for future research}

Despite these limitations, a key finding remains clear. Although Canadian researchers have contributed to scholarship on the topic of educational integrity over the past quarter decade or so, Canada has yet to develop substantive and consistent contributions to research. As a nation, Canada is poised to join the global dialogue on integrity, but there is a definitive need for an overall increase in attention to educational integrity from a Canadian research perspective. As a result, we propose the following five concrete recommendations.

Recommendation 1: National-scale research. Given that our study found limited contributions to Canadian research on academic integrity on a national scale, we recommend the development, initiation and implementation of large-scale national research projects to elevate the overall understanding of what is happening across the nation broadly.

Naylor et al. (2017) stated that extramural research is that conducted by scientists and scholars who work in higher education institutions and other affiliated organizations outside of government, while intramural research is conducted by those employed by government agencies and departments. Canadian researchers must engage in advocacy and policy work with government agencies, including provincial ministries of education, as well as the national Council of Ministers of Education, Canada. To that end, we recommend that both extramural and intramural research be undertaken to better understand the national landscape of educational integrity in Canada.

Recommendation 2: Increase in funding and support for educational integrity research. There is a need for investigator-led research in Canada generally (Naylor et al. 2017). This includes research that is "discovery-oriented, inquiry driven, or simply 'independent", that is free from pressures of "priority-driven research" that may need to meet the pressures of partnership with business or government to achieve particular outcomes (p. i). Educational integrity in Canada is no exception to this need for independent, investigator-led research. Publicly funded research, in particular, elevates the legitimacy of researchers, as well as the institutions with whom they are affiliated (Cunningham et al. 2014). In other words, funded research is judged to be more legitimate and respectable, so in order research in this field to advance, it must be funded.

To our knowledge, no other Anglophone researchers have received national SSHRC funding to engage in research related to educational integrity since Taylor, Usick and Patterson in the early 2000s. In Canada, academic integrity needs to be elevated in terms of its legitimacy as a field of scientific and scholarly inquiry and one effective way to achieve this is to increase funding both in terms of publicly available research grants, as well as smaller institutional grants.

Recommendation 4: An increase in discipline-specific research. As we have shown, there has been a moderate amount of investigation into educational integrity in health-related fields, and a minimal amount in business and engineering. We argue that there is insufficient evidence in the studies we found to present an adequate picture the state of educational integrity across Canadian higher education by discipline. If Canadian institutions are to develop evidence-informed policies, procedures, as well as faculty development programs and student academic integrity tutorials and other training, then we cannot rely exclusively on evidence from other countries.

Recommendation 5: French-language contributions to research on academic integrity. As a bilingual nation, research on academic integrity in Canada must be represented in 
both official languages. Although we are aware of the success of Peters's (2015) award-winning article "Enseigner les stratégies de créacollage numérique pour éviter le plagiat au secondaire" in the Canadian Journal of Education, for her SSHRC-funded Francophone project, our lack of proficiency in French meant we could not include it in our review. French-language literature on academic integrity exists in Canada and merits further investigation. As such, we call for our Francophone colleagues to conduct a companion literature review in French to complement this work.

Recommendation 5: A cross-national review of research. We have conducted our review of the literature on and about the Canadian context as the first stand-alone analysis of its kind. Now that a comprehensive data set has been established, a natural next step would be to broaden the scope of the work, comparing the existing research in and about Canada with that of other countries. This would further situate Canada within the scholarly global context, showing its contributions to the educational integrity literature in relation to similar nations.

\section{Conclusions}

At the beginning of our study, we asked this research question: What major themes emerge from scholarly and research literature about academic integrity in the Canadian context? We found a total of 56 sources, almost evenly divided between descriptive and analytical works. Although the number of research outputs has increased over the past decade, the field of educational integrity research has yet to mature in Canada. This is further evidenced by what appears to be a lack of sustained research over time by a critical mass of researchers and graduate students who do not seem to go on to research academic integrity later in their careers.

Canada's Advisory Panel on Federal Support for Fundamental Science found that worldwide, Canada does not rank in the top 30 nations, including non-OECD nations, in terms of research intensity (Naylor et al. 2017, p. i). What the Naylor report found about the situation of research in Canada as a whole, also relates to educational integrity on a smaller scale: to date, Canada has demonstrated a lack of research intensity with regards to academic integrity, which we contend needs to be remedied.

In their review of published research on academic integrity written by Australasian authors, Fielden and Joyce (2008) noted that the relative contributions of Australia outnumbered those of New Zealand, which they argued was "not surprising given the respective population sizes". While this conclusion has merit, we contend that population constitutes only one piece of the puzzle. With a population of 35 million (Statistics Canada 2017a), Canada is larger than the combined population of Australia with its population of 24 million (Australian Bureau of Statistics 2018) and New Zealand with close to 4.9 million (NZ Stats). Fielden and Joyce's review a decade ago analyzed 125 published papers, which was more than twice the number we found for Canada. This further substantiates the notion that factors beyond population size play a role in a country's contributions to the research literature. Developing a corps of scholars with dedicated programmes of research, supported by funding, are key factors in ensuring that Canada can add meaningful contributions to the global dialogue on integrity.

Our reviews shows that Canada is not immune to issues relating to integrity (and breaches of it), but rather that research contributions from Canada are notably impoverished. As such, we conclude this review with a call for an increase in evidence-based, 
investigator-led, and funded research to better understand the particular characteristics of educational integrity in Canada and more intense participation in the ongoing global dialogue about integrity.

\section{Acknowledgements}

The authors also wish to thank Erin Seatter for her professional editing of the manuscript. We also wish to thank the librarians at the University of Calgary who assisted us in locating sources that were not readily available through our institutional databases. We also express our gratitude to the anonymous reviewers, whose thorough and thoughtful review of our work allowed us to improve it before publication. Finally, we thank the editorial and production team at the journal who helped with the final preparations of the manuscript.

Funding

This research was funded by a University of Calgary Werklund School of Education Research Development Grant (\#1043605).

\section{Availability of data and materials}

The datasets generated and/or analysed during the current study are available in the Open Science Framework repository, DOI: https://doi.org/10.17605/OSF.IO/EZCKB.

\section{Authors' contributions}

SE $80 \%$. RIE 20\%. SE designed the research project, conducted the literature search, analyzed the content, drafted the manuscript, prepared figures and tables and undertook revisions provided by peer reviewers. RE prepared an annotated bibliographic of sources that aided with the analysis. Both authors read and approved the final manuscript.

\section{Ethics approval and consent to participate}

N/A

\section{Competing interests}

The authors declare that they have no competing interests.

\section{Publisher's Note}

Springer Nature remains neutral with regard to jurisdictional claims in published maps and institutional affiliations.

Received: 21 February 2018 Accepted: 25 June 2018

Published online: 25 July 2018

\section{References}

Alphonso C (2017) Former TDSB director guilty of plagiarizing his PhD, panel says. The Globe and Mail. https://www. theglobeandmail.com/news/toronto/former-tdsb-director-guilty-of-plagiarizing-his-phd-panel-says/article35403977. Accessed 13 June 2018

Altbach PG (2015) Academic corruption: the continuing challenge. Internet High Educ (38):5-6. https://doi.org/10.6017/ ihe.2005.38.7454

Austin Z, Collins D, Remillard A, Kelcher S, Chuia S (2006) Influence of attitudes toward curriculum on dishonest academic behavior. Am J Pharm Educ 70(3):1-9

Austin Z, Simpson S, Reynen E (2005) The fault lies not in our students, but in ourselves': academic honesty and moral development in health professions education-results of a pilot study in Canadian pharmacy. Teach High Educ 10(2):143-156. https://doi.org/10.1080/1356251042000337918

Australian Bureau of Statistics (2018) Australian demographic statistics, 2017. http://www.abs.gov.au/AUSSTATS/abs@. nsf/mf/3101.0. Accessed 13 June 2018.

Australian Government Tertiary Education Quality and Standards Agency (TESQA). (2015). Report on Student Academic Integrity and Allegations of Contract Cheating by University Students. https://files.eric.ed.gov/fulltext/ED564140.pdf Accessed 13 June 2018

Baetz M, Zivcakova L, Wood E, Nosko A, Pasquale D, Archer K (2011) Encouraging active classroom discussion of academic integrity and misconduct in higher education business contexts. J Acad Ethics 9(3):217-234. https://doi. org/10.1007/s10805-011-9141-4

Bens SL (2010) Senior education students' understandings of academic honesty and dishonesty. In: Dissertation. University of Saskatchewan

Bertram Gallant, T. (Ed.) (2012). Al Reader: Twenty years of top academic integrity research: International Center for Academic Integrity.

Bokosmaty S, Ehrich J, Eady MJ, Bell K (2017) Canadian university students' gendered attitudes toward plagiarism. J Further High Educ:1-15. https://doi.org/10.1080/0309877X.2017.1359505.

Booth A, Papaioannou D, Sutton A (2012) Systematic approaches to a successful literature review. Sage, Thousand Oaks

Bretag T (2014) Challenges in addressing plagiarism in education. PLoS Med 10(12):e1001574. https://doi.org/10.1371/ journal.pmed.1001574

Bretag T (2017) Good practice note: Addressing contract cheating to safeguard academic integrity. https://www.tegsa. gov.au/latest-news/publications/good-practice-note-addressing-contract-cheating-safeguard-academic. Accessed 13 June 2018

Bretag, T., Harper, R., Burton, M., Ellis, C., Newton, P., Rozenberg, P.,... van Haeringen, K. (2018). Contract cheating: a survey of Australian university students. Stud High Educ, 1-20. 
Broussard A, Golson B (2000) High school honor code curbs cheating. Educ Dig 65(6):27. https://doi.org/10.1080/ 03075079.2018 .1462788$.

Busch P, Bilgin A (2014) Student and staff understanding and reaction: academic integrity in an Australian university. J Acad Eth 12(3):227-243. https://doi.org/10.1007/s10805-014-9214-2

Butakov S (2014) Crowd crawling approach for community based plagiarism detection service. In: Paper presented at the 23rd International Conference on World Wide Web, Seoul, Korea, 7-11 April 2014

Butakov S, Barber C (2012) Protecting student intellectual property in plagiarism detection process. Br J Educ Technol 43(4):E101-E103. https://doi.org/10.1111/j.1467-8535.2012.01290.x

Butakov S, Dyagilev V, Tskhay A (2012) Protecting students' intellectual property in the web plagiarism detection process. Int Rev Res Open Distance Learn 13(5):1-19

Butakov S, Murzintsev S, Tskhai A (2016) Detecting text similarity on a scalable no-SQL database platform. In: Paper presented at the 2016 International Conference on Platform Technology and Service, Jeju, Korea, 15-17 February 2016

Butakov S, Shcherbinin V (2009) The toolbox for local and global plagiarism detection. Comput Educ 52(4):781-788. https://doi.org/10.1016/j.compedu.2008.12.001

Butakov S, Shcherbinin V, Diagilev V, Tskhay A (2013) Embedding plagiarism detection mechanisms into learning management systems. In: Kats $Y$ (ed) Learning management systems and instructional design: best practices in online education. IGI Global, Hershey

Canadian Society for the Study of Higher Education (2018) CJHE Sheffield Award. https://csshe-scees.ca/awards/cjhesheffield-award. Accessed 13 June 2018.

Caravello PS (2007) The literature on academic integrity and graduate students: issues, solutions, and the case for a librarian role. Pub Serv Quart 3(3/4):141-171

Carroll J, Duggan F (2005) Institutional change to deter student plagiarism: what seems essential to a holistic approach? In: Paper presented at the 2nd Asia-Pacific Educational Integrity Conference, University of Newcastle, Callaghan, Australia, 2-3 December 2005

Christensen Hughes JM, McCabe DL (2006a) Academic misconduct within higher education in Canada. Can J High Educ 36(2):1-21

Christensen Hughes JM, McCabe DL (2006b) Understanding academic misconduct. Can J High Educ 36(1):49-63

Clarke R, Lancaster T (2006) Eliminating the successor to plagiarism: Identifying the usage of contract cheating sites. In: Paper presented at the 2nd international plagiarism conference, Gateshead, United Kingdom, June 2006

Colella J (2012) Plagiarism self-reported rates, understandings, and education among teacher candidates in a faculty of Education, Thesis. University of Windsor

Colella-Sandercock JA (2016) Self-reporting in plagiarism research: how honest is this approach? J Res Pract 12(2):1-5

Colella-Sandercock JA, Alahmadi HW (2015) Plagiarism education: strategies for instructors. Int J Learn Teach Educ Res 13(1):76-84

Colella-Sandercock JA, Alahmadi HW (2016) Rethinking pedagogy: How the implementation of transformative teaching and learning can help reduce plagiarism. In: PowerPoint for paper presented at the 10th Annual International Conference on Teaching and Learning. Oakland University, Rochester https:/www.oakland.edu/Assets/Oakland/cet// files-and-documents/Conferences/ConferencePPTs/491RethinkPlagiarismCollella-Sandercock.pdf. Accessed 12 Feb 2018

Council of Ministers of Education, Canada (2018) https://www.cmec.ca/en. Accessed 13 June 2018.

Creswell JW (2012) Educational research: planning, conducting, and evaluating quantitative and qualitative research, 4th edn. Pearson, Boston

Cunningham J, O'Reilly P, O'Kane C, Mangematin V (2014) The inhibiting factors that principal investigators experience in leading publicly funded research. J Technol Transf 39(1):93-110. https://doi.org/10.1007/s10961-012-9269-4

Das M, Henderson E (2015) Factors influencing students' perception of academic misconduct: findings from an Atlantic Canada study. Int J Hum Resour Manag 3(1):86-99

Eaton SE (2017) Comparative analysis of institutional policy definitions of plagiarism: a pan-Canadian university study. Interchange 48(3):271-281. https://doi.org/10.1007/s10780-017-9300-7

Eaton SE, Guglielmin M, Otoo B (2017) Plagiarism: Moving from punitive to pro-active approaches. In: Preciado Babb AP, Yeworiew L, Sabbaghan S (eds) Selected Proceedings of the IDEAS Conference 2017: Leading Educational Change Conference. Werklund School of Education, University of Calgary, Calgary, pp 28-36

Edmonds K (2006) Off with their heads! Copyright infringement in the Canadian online higher educational environment. Can J Learn Technol 32(2):11-31

Ercegovac Z, Richardson JV (2004) Academic dishonesty, plagiarism included, in the digital age: a literature review. Coll Res Libr 65(4). https://doi.org/10.5860/crl.65.4.301

Evans-Tokaryk T (2014) Academic integrity, remix culture, globalization: a Canadian case study of student and faculty perceptions of plagiarism. Across Discipl 11(2):1-40

Fielden K, Joyce D (2008) An analysis of published research on academic integrity. Int J Educ Integr 4(2):4-24. https:// doi.org/10.21913/IJEl.v4i2.411.

Foltýnek T, Glendinning I (2015) Impact of policies for plagiarism in higher education across Europe: results of the project. Acta Univ Agric Silvic Mendel Brun 63(1):207-216. https://doi.org/10.11118/actaun201563010207

Fredeen SM (2013) Discourses of im/possibility: International students at a Canadian university, Dissertation. University of Alberta

Gallwey T (1879) Plagiarism or coincidence: which? Ir Mon 7:312-319

Genereux RL, McLeod BA (1995) Circumstances surrounding cheating: a questionnaire study of college students. Res High Educ 36(6):687-704. https://doi.org/10.1007/BF02208251

Glendinning I (2013) Comparison of policies for academic integrity in higher education across the European Union. http://ketlib. lib.unipi.gr/xmlui/bitstream/handle/ket/814/Comparison\%20of\%20policies\%20for\%20Academic\%20Integrity\%20in\% 20Higher\%20Education\%20across\%20the\%20European\%20Union.pdf?sequence=2 Accessed 13 June 2018.

Glendinning I (2014) Responses to student plagiarism in higher education across Europe. Int J Educ Integr 10(1):4-20. https://doi.org/10.21913/JEl.v10i1.930

Griffith J (2013) Pedagogical over punitive: the academic integrity websites of Ontario universities. Can J High Educ 43(1):1-22 
Groark M, Oblinger DG, Choa M (2001) Term paper mills, anti-plagiarism tools, and academic integrity. Educ Rev:40-48 Hage HS (2010) Academic dishonesty in the Canadian classroom: Examination of the attitudes and behaviours of a sample of university students in Regina, Thesis. University of Regina

Harper R, Bretag T, Ellis C, Newton P, Rozenberg P, Saddiqui S, van Haeringen K (2018) Contract cheating: a survey of Australian university staff. Stud High Educ:1-17. https://doi.org/10.1080/03075079.2018.1462789

Hexham I (1992) On plagiarism and integrity in scholarly activity. Humanist Humanit Comput 5(4) http://dhhumanist. org/Archives/Nirginia/v05/0795.html. Accessed 12 Feb 2018

Hexham I (2005) The plague of plagiarism: Academic plagiarism defined. http://people.ucalgary.ca/ hexham/content/ articles/plague-of-plagiarism.html. Accessed 12 Feb 2018.

Hexham I (2013) The plague of plagiarism: Academic plagiarism defined. https://www.researchgate.net/profile/lrving Hexham/publication/236899249_The_Plague_of_Plagiarism_Academic_Plagiarism_Defined_Originally_published_ as_On_Plagiarism_and_Integrity/links/00b4951a21c5e03a4c000000.pdf. Accessed 12 Feb 2018

Hu J (2001) The academic writing of Chinese graduate students in sciences and engineering: processes and challenges, Dissertation. University of British Columbia

Joyce D (2007) Academic integrity and plagiarism: Australasian perspectives. Comput Sci Educ 17(3):187-200. https:// doi.org/10.1080/08993400701538062

Jurdi R, Hage HS, Chow HPH (2011) Academic dishonesty in the Canadian classroom: Behaviours of a sample of university students. Can J High Educ 41(3):1-35

Jurdi R, Hage HS, Chow HPH (2012) What behaviours do students consider academically dishonest? Findings from a survey of Canadian undergraduate students. Soc Psychol Educ 15(1):1-23. https://doi.org/10.1007/s11218-011-9166-y

Kara F, MacAlister D (2010) Responding to academic dishonesty in universities: a restorative justice approach. Contempt Justice Rev 13(4):443-453. https://doi.org/10.1080/10282580.2010.517981

Kelleher WE (2016) Canadian laws relevant to university student academic discipline, Dissertation. Northcentral University

Kier CA (2013) Is it still cheating if it's not done on purpose? Accidental plagiarism in High Education PowerPoint for paper presented at the 2013 Hawaii International Conference on Education, Honolulu, 5-9 January 2013. https:// auspace.athabascau.ca/handle/2149/3316. Accessed 12 Feb 2018.

Kier CA (2014a) Accidental plagiarism in higher education: Part II. Paper presented at the 2014 Hawaii international conference on education, Honolulu, 5-8 January 2014. http://hdl.handle.net/2149/3430. Accessed 12 Feb 2018.

Kier CA (2014b) How well do Canadian distance education students understand plagiarism? Int Rev Res Open Distance Learn 15(1):227-248

Kier CA (2015) Can serious games prevent plagiarism? In: Paper presented at the E-Learn: World Conference on eLearning in Corporate, Government, Healthcare, and High Educ, Chesapeake, 19-22 October 2015

Leo G (2017a) U of R engineering profs warned about teaching assistants taking bribes to increase grades. CBC News. http://www.cbc.ca/news/canada/saskatchewan/unviersity-of-regina-engineering-teaching-assistants-1.4369110. Accessed 13 June 2018.

Leo G (2017b) U of R grades hacked through dean's computer account, according to internal email. CBC News. http:// www.cbc.ca/news/canada/saskatchewan/university-of-regina-engineering-grades-hacked-dean-1.4368984. Accessed 13 June 2018.

Leo G (2018) U of Regina suspects 'significant' number of students cheated in law and ethics class. CBC News. http:// www.cbc.ca/news/canada/saskatchewan/university-regina-engineering-cheating-1.4567955. Accessed 13 June 2018.

Leonard M, Schwieder D, Buhler A, Beaubien Bennett D, Royster M (2015) Perceptions of plagiarism by STEM graduate students: a case study. Sci Eng Ethics 21(6):1587-1608. https://doi.org/10.1007/s11948-014-9604-2

Lytton H (1996) "This is how it's always been done": the treatment of academic misconduct in Canada. Can J Socio 21 (2):223-235. https://doi.org/10.2307/3341978

Macfarlane B, Zhang J, Pun A (2014) Academic integrity: a review of the literature. Stud High Educ 39(2):339-358. https://doi.org/10.1080/03075079.2012.709495

MacLeod PD (2014) An exploration of faculty attitudes toward student academic dishonesty in selected Canadian universities, Dissertation. University of Calgary http://hdl.handle.net/11023/1370. Accessed 12 Feb 2018

McCabe D (1992) The influence of situational ethics on cheating among college students. Sociol Inq 62(3):365-374. https://doi.org/10.1111/j.1475-682X.1992.tb00287.x

McCabe D (2016) Cheating and honor: lessons from a long-term research project. In: Bretag T (ed) Handbook of academic integrity. Springer, Singapore

McCabe DL (1993) Faculty responses to academic dishonesty: the influence of student honor codes. Res High Educ 34(5):647-658

McCabe DL, Trevino LK (1993) Academic dishonesty: honor codes and other contextual influences. J High Educ 64(5): 522-538. https://doi.org/10.2307/2959991

McCabe DL, Trevino LK, Butterfield KD (1999) Academic integrity in honor code and non-honor code environments: a qualitative investigation. J High Educ 70(2):211-234. https://doi.org/10.1080/00221546.1999.11780762

McCabe DL, Trevino LK, Butterfield KD (2001) Cheating in academic institutions: a decade of research. Ethics Behav 11(3):219-232. https://doi.org/10.1207/S15327019EB1103_2

McCabe DL, Trevino LK, Butterfield KD (2002) Honor codes and other contextual influences on academic integrity: a replication and extension to modified honor code settings. Res High Educ 43(3):357-378

Miron JB (2016) Academic integrity and senior nursing undergraduate clinical practice. In: Dissertation. Queen's University

Mostrous A, Kenber B (2016) Universities face student cheating crisis. The Sunday Times. https://www.thetimes.co.uk article/universities-face-student-cheating-crisis-9jt6ncd9vz7. Accessed 13 June 2018.

Naylor CD, Birgeneau RJ, Crago M, Lazaridis M, Malacrida C, McDonald AB, Piper MC, Quirion R, Wilson A. (2017). Investing in Canada's future: Strengthening foundations for Canadian research. http://www.sciencereview.ca/eic/ site/059.nsf/vwapj/sciencereview_april2017.pdf/\$file/sciencereview_april2017.pdf. Accessed 13 June 2018.

Neufeld J, Dianda J (2007) Academic dishonesty: A survey of policies and procedures at Ontario Universities. http://cou. on.ca/wp-content/uploads/2015/07/Academic-Colleagues-Academic-Dishonesty-A-Survey-of-Policies-andProcedures-at-Ontario-Universities.pdf. Accessed 12 February 2018. 
Oliphant T (2002) Cyber-plagiarism: plagiarism in a digital world. Feliciter 48(2):78

Paterson B, Taylor L, Usick B (2003) The construction of plagiarism in a school of nursing. Learn Health Soc Care 2(3): 147-158. https://doi.org/10.1046/j.1473-6861.2003.00047.x

Peters M (2015) Enseigner les stratégies de créacollage numérique pour éviter le plagiat au secondaire. Can J Educ 38(3): $1-28$

Petticrew M, Roberts H (2006) Systematic reviews in the social sciences: a practical guide. Blackwell, Malden

Quality Assurance Agency for Higher Education (2016) Plagiarism in higher education - Custom essay writing services: an exploration and next steps for the UK higher education sector. http://www.qaa.ac.uk/publications/informationand-guidance/publication?PubID=3107\#.WgrONZPwZm8. Accessed 13 June 2018.

Quality Assurance Agency for Higher Education (2017) Contracting to cheat in higher education: How to address contract cheating, the use of third-party services and essay mills. http://www.qaa.ac.uk/en/Publications/ Documents/Contracting-to-cheat-in-higher-education.pdf. Accessed 13 June 2018.

Shen A (2017) Naylor report lays the groundwork to renew basic research in Canada. University Affairs. https://www. universityaffairs.ca/news/news-article/naylor-report-lays-groundwork-renew-basic-research-canada. Accessed 13 June 2018

Statistics Canada (2017a) Canada at a glance. https://www150.statcan.gc.ca/n1/pub/12-581-x/2017000/pop-eng.htm. Accessed 13 June 2018.

Statistics Canada. (2017b). Postsecondary enrolments, by student status, country of citizenship and sex. http://www5. statcan.gc.ca/cansim/a26?lang=eng\&retrLang=eng\&id=4770031\&\&pattern=\&stByVal=1\&p1=1\&p2=31\&tabMode= dataTable\&csid=. Accessed 18 May 2018.

Strawczynski J (2004) When students won't Turnitin: an examination of the use of plagiarism prevention services in Canada. Educ Law J 14(2):167-190

Taylor KL, Usick BL, Paterson BL (2004) Understanding plagiarism: the intersection of personal, pedagogical, institutional, and social contexts. J Excell Coll Teach 15(3):153-174

Thyret-Kidd A (2012) One university's reported cases of academic dishonesty, Thesis. Nipissing University

Usick BL (2005) Is plagiarism an issue in graduate education? An examination of two graduate programs. Thesis, University of Manitoba. http://search.proquest.com/docview/305088192/abstract. Accessed 12 Feb 2018.

Wangaard DB (2016) Practices to support developing academic integrity in secondary school students. In: Bretag T (ed) Handbook of academic integrity. Springer, Singapore

Wideman M (2008) Academic dishonesty in postsecondary education: a literature review. Transform Dialogues 2(1):1-12

Wideman M (2009) Caring, sharing, coping and control: Academic dishonesty and the nursing student. PhD thesis, University of Toronto. https://www.researchgate.net/publication/261993093_CARING_SHARING_COPING_AND_ CONTROL_ACADEMIC_DISHONESTY_AND_THE_NURSING_STUDENT. Accessed 12 Feb 2018.

Wideman M (2010) Academic dishonesty in a school of nursing. http://www.iiis.org/CDs2010/CD2010IMC/ICETI_2010/ PapersPdf/EB142ZD.pdf. Accessed 12 Feb 2018.

Wideman M (2011) Caring or collusion? Academic dishonesty in a school of nursing. Can J High Educ 41(2):28-43

Woods JT (1998) Academic integrity policies and practices in common law Canadian universities: An examination of compliance with natural justice, Dissertation. Bowling Green State University

Woods P, Negrin K (2016) Supporting academic integrity for internationally educated nurses: building a foundation for academic and professional success. PowerPoint for paper presented at the British Columbia Council for International Education, Victoria, 19-22 June 2016. http://bccie.bc.ca/wp-content/uploads/2016/06/supportingacademic-integrity.pdf. Accessed 12 Feb 2018.

Zivcakova L, Wood E, Baetz M, De Pasquale D (2012a) How do faculty members respond to their students' discussions of academic misconduct and academic integrity? Int J Educ Integr 8(1):25-40. https://doi.org/10.21913/JEI.v8i1.782

Zivcakova L, Wood E, Forsyth G, Dhillon N, Ball D, Corolis B et al (2012b) Examining the impact of dons providing peer instruction for academic integrity: dons' and students' perspectives. J Acad Ethics 10(2):137-150. https://doi.org/10. 1007/s10805-012-9153-8

Zivcakova L, Wood E, Forsyth G, Zivcak M, Shapiro J, Coulas A et al (2014) Investigating perceptions of students to a peer-based academic integrity presentation provided by residence dons. J Acad Ethics 12(2):89-99. https://doi.org/ 10.1007/s10805-014-9206-2

\section{Submit your manuscript to a SpringerOpen ${ }^{\circ}$ journal and benefit from:}

- Convenient online submission

- Rigorous peer review

Open access: articles freely available online

- High visibility within the field

- Retaining the copyright to your article

Submit your next manuscript at $\gg$ springeropen.com 